\title{
Celto-Slavic Parallels in Mythology and Sacral LeXicon
}

\author{
VÁCLAV BLAŽEK
}

\section{Old Irish Dagdae < Celtic *dago-dēuo- 'good-god' $\sim$ Slavic * Dažbbogz} Old Irish Dagdae was the highest god of the Goidelic pantheon. His name reflects Celtic *dago-deuio- which can be interpreted as 'belonging to a good god'. This form indicates the existence of the Celtic compound *dago-dèuo- 'good god', which structurally corresponds to Old Indic Vásudeva- (AV), the father of Krṣnán-. The first component is well attested in both Insular and Continental Celtic languages: Old Irish dag 'good' (.i. maith), frequently used in compounds, e.g. dag-duine 'good man'; Welsh, Cornish, Breton $d a$ 'good', Old Welsh degion pl. 'nobles' $<*$ dagiones (Falileyev 2000: 42); cf. also Old Brythonic *dag- in the inscription from Bath ANDAGIN < acc. f. *ande-dagin 'very good'.

The component *dago- was very productive in formation of the Gaulish anthroponyms, e.g. Dago-bitus (and Bitu-daga), Dago-dubnus, Dago-marus, Dago-rix, Dago-uassus, Dagissius, Dagillus (Delamarre 2001: 112). The Gaulish appellative is attested in the inscription from Sens: GENETA IMI DAGA UIMPI "fille suis bonne (et) belle" (LEIA 1996: D 7-8; cit. Delamarre 2001: 112). In the Welsh tradition the semantically corresponding name can be identified in Math: Math uab Mathonwy oed arglwyd ar Wyned "Math, son of Mathonwy, in this time the ruler over Gwynedd" (Puhvel 1987: 178), known from the Fourth Branch of Mabinogi. His name has been connected with Welsh mad, pl. madyoet / madioedd 'good', Cornish mas, Middle Breton mat, Breton mad 'id.'; Old Irish maith 'id.' (Celtic $*_{\text {mati-) }}$ and further the $u$-stem in Celtiberian m.a.Tu.ś (Meid $1993=$ Botorrita I A: line 6) and Gaulish (Coligny) matu expressing the 'right time', cf. also the epithet Matuicos of Apollon (LEIA: M 12-13; de Bernardo Stempel 1999: 534-35, fn. 50).

According to Abayev (1971: 13) the Slavic equivalent of Celtic *Dagodèuo- should be identified with Church Slavonic (Russian redaction) Dažbbogz, Old Russian Daždbbogz, Serbo-Croatian Dàžbog. It has usually been interpreted as the imperative 'give! god' (ESSJ 1977: IV 182-83). 
The theonym Dažbbogъ is quoted in Vladimir's pantheon in Nestor's Chronicle:

I nača knjažiti Volodimerъ vъ Kievě edinъ, i postavi kumiry na xolmu vně dvora teremnago: Peruna drevjana, a glavu ego srebrenu, a usъ zlatъ, $i$ Xъrsa, Dažbboga （Tschižewskij 1969: 77).

And Vladimir became a sole ruler in Kiev. He erected idols on the hill outside the palace's yard: the wooden [idol of] Perun with his head of silver and his moustache of gold, and [the idols of] Khors, Dazh'bog.

The pair Xorsb \& Dažbbogъ occurs in the later text Prolozhnoe zhitiye Knyazya Vladimira: prišed v v Kievъ izbi vsja idoly i Peruna, Xursa, Dažbboga i Mokošb (Ivanov \& Toporov 1983: 180-81) "He came to Kiev [and] destroyed all the idols of Perun, Khors, Dazh'bog and Mokosh"”. The same sequence of the theonyms Xorsъ \& Dažbbogъ occurs in many other medieval Russian chronicles and the former could be an epithet of the latter. This conclusion agrees with the etymology of Xorsz. The theonym Xorss can reflect an adaptation of the epithet *xwarza- 'good' of some Sarmatian deities, cf. Ossetic Digor xwarz, Iron xorz 'good'. Russian khoroshij 'good' was borrowed from a close source, probably Alanic (Abayev 1989: 217-19).

In Slovo o polku Igoreve, the idiom Daždbboža vnuka [verse 158], Dažbboža vnuka [verse 192], i.e. "the grandson of Dažbbogz" is used collectively for 'Russian people' (Stelletsky 1981: 13). It resembles the epithet Ollathair 'all-father' of Dagdae:

Aed Abaid Essa Rūaid misi i.i. Dagdia druìdechta Tūath Dē Danann ${ }_{7}$ in Rūad Rofessa ${ }_{7}$ Eochaid Ollathair mo trī hanmanna.

I am Aed Abaid Essa Ruaid; Dagdae of druidic wisdom of the Túatha dé Danann, the Mighty One of Great Knowledge, and Eochaid All-Father are my three (other) names (YBL: fol. 176; Olmsted 1994: 43).

Etymology: The Celtic protoform *dago-dèuo- would be borrowed into Slavic as *dogoděvъ. It is quite possible that after identification with $* d i v ъ$ with its negative semantics the second component was replaced by positive *bogz. On the other hand, Slavic *dažb- implies a source of the type *dāgi- or *dōgi-. For latter protoform, see Old/Middle Irish dóig dáig 1. 'likely, probable, to be expected; desirable, an object of liking; proper, right'; 
2. 'opinion, supposition; hope, expectation, confidence' (DIL: D 303-04). The same base may be instanced in the Gaulish man's name Dogir[ix] (Holder 1896: I 1301). ${ }^{1}$ The final $-i$ - also occurs in Gaulish compounded anthroponyms containing the component $* d a g-{ }^{2}$ If the preceding thoughts are correct, the Celtic material probably reflects the apophonic pair *dagovs. ${ }^{*}$ dogi- $<*$ dogo- vs. ${ }^{*}$ doHgi-. The most promising attempt to cross the borders of the Celtic branch seems to be the idea of Stokes \& Bezzenberger (1894: 140; see also Holder 1896: I 1214), to connect Celtic *dago- with the Germanic verb attested in the same apophonic grades: Gothic tekan, 3 sg. pret. taitok 'to touch', Old Icelandic taka, pret. tók 'to touch, take, seize' (Lehmann 1986: 342), cf. also toekr 'fair, acceptable, legal', lit. 'was angenommen werden kann'< *tōkja- (de Vries 1962: 604). Slavic *dažbexactly corresponds to Celtic $* d \bar{o} g i$. From the point of view of grammatical determination, the pattern ${ }^{*} C \bar{o} C-i$ - reflects the verbal nouns in Old Irish: dáir, gen. dára 'a bulling' < *dhor-i-: dairid 'bulls', cáil 'spear' < *kōl-i-, gáir 'shout, cry' < * $\hat{g}^{h} \bar{o} r-i$-, etc. (de Bernardo Stempel 1999: 66). Hypothetically, it is perhaps plausible to reconstruct the primary meaning of the Celtic abstract noun *dogi- \pm "goodness".

Both the common heritage and the adaptation of the Celtic theonym can be seen here. But for the first solution there is no support from Slavic. The second argument for borrowing may be found in Baltic: Lithuanian dãžnas 'mancher, manch einer, häufig', adv. dažnaĩ, Latvian dažs 'mancher, verschiedenartig, mannigfaltig', daza, dazums 'grosse Menge' (Fraenkel 1962: 84) may reflect $* d \partial \hat{g}$ - with the regular satom-reflexes of the palatal velar, in contrast to Slavic, where $*_{-z ̌}$ - was regularly palatalised from $*_{-} g$ before $*_{b}$. Summing up, it seems probable that the Slavic theonym *Dažbbog $ъ$ was adapted from the unattested Celtic compound *dogidēuo- 'goodness-god'.

\section{Old Irish Macha $<$ Celtic *Makasiä $\sim$ Slavic *Mokošb}

There were three Old Irish goddesses or heroines of the same name, Macha (DIL: M 12):

(a) One of the three daughters of Ernmas and sister of Badb and Mórrigu: tri ingena ... oc Ernmais .i. Badb , Macha , Mórrigu (LL: 1179).

Cf. Delamarre's (2001: 220) reading Doci-rix.

2 Cf. Virion-dagi-cane (Schmidt 1957: 297), also -dagi-cane 'gut singend'? (ibid. 161), where -cane is in the dative. 
(b) Wife of Neimed (Comyn \& Dinneen 1902: 176).

(c) Wife of Cruinniuc (YBL: fol. 211 $\left.{ }^{\mathrm{b}} 40\right){ }^{3}$

The name is derivable from three alternative Celtic protoforms: *makViā, *makVviā, *makVsiā (LEIA: M 3-4), where V represents Celtic *a or *o. The Celtiberian word in acc. sg. m.a.Ka.ś.i.[V]m (Meid 1993, 29, $99=$ Botorrita I A: line 5) may serve as a witness for the alternative *makasiā (de Bernardo Stempel 1999: 263-64; Wodtko 2000: 241-42).

It was Viktor Kalygin (1997: 369-71) who first recognised the parallelism of the protoform *Makasiā with Slavic Mokošb, practically the only known goddess of the Slavic pantheon. The theonym is first quoted in Vladimir's pantheon in Nestor's Chronicle (AD 980):

I nača knjažiti Volodimerъ vъ Kievě edinъ, i postavi kumiry na xolmu vně dvora teremnago: Peruna drevjana, a glavu ego srebrenu, a usъ zlatъ, ... i Striboga, i Simarbgla, i Mokošb (Tschižewskij 1969: 77).

And Vladimir became a sole ruler in Kiev. He erected idols on the hill outside the palace's yard: the wooden [idol of] Perun with his head of silver and his moustache of gold, and [the idols of] ... Stribog, Simargl and Mokosh'.

Both here, and in the text Slovo nekoyego khristolyubtsa, the theonym stands in opposition to all 'male' deities:

Iže moljațsja ognevi pod ovinom, vilamъ, Mokoši, Simou, Rbglou, Perounou, Volosu skotbju bogu, Xъrsou, rodou, rožanicjamъ $i$ vsěmъ prokljatymъ bogomъ $i x ъ . .$. (Ivanov \& Toporov 1983: 178)

Those who pray to the fire at the barn, to vilas, to Mokosh', to Sim, to Regl, to Perun, to Volos the cattle god, to Khors, to Rod, to rozhanitsas and to all the other damned gods.

Elsewhere the same text informs us about a continuing paganism:

I věroujutb vъ Perouna, $i$ vъ X Xrsa $i$ vb Sima, $i$ vb Rbgla, $i$ vъ Mokošb, $i$ vb vily, ixže čisloms tridesjate sestrenicb - glagoljutb okanbnii-nevěglasi, $i$ mnjatb bogynjami, i tako kladoutb ims treby $i$ korovai ims moljatb, koury rěžjutb. ... Těmъ že bogoms trebou kladoutb i tvorjatb i slovensskyi jazyk: vilams i Mokošbi, Divě, Perounou, Xırsu, rodu i rožanicam, upiremb $i$

\footnotetext{
According to another version of the legend on the provenance of the name Macha, Macha Mongrúad was the daughter of the High-king Áed Ruad (see LL: 2528). Cf. also a similar account in Comyn \& Dinneen 1908: 152. [Eds.]
} 
bereginjams i Pereplutu i verbtjačesja pbjutb emou vъ rozěxъ... (Ivanov \& Toporov 1983: 179).

And they believe in Perun, in Khors, in Sim, in Regl, in Mokosh', and in vilas - and thirty sisters is their number (as the cursed ones say). They are ignorant and they consider vilas to be goddesses, and perform rites in their honour, and hallow round breads in their honour, and slaughter hens ... They perform rites in honour of the same gods in the Slavic language: [in honour of] vilas, Mokosh', Div, Perun, Khors, Rod, and rozhanitsas, vampires, bereginyas, Pereplut. They sing in his honour wearing masks and revolving in a ring.

Here some erotic practices were ascribed to Mokošb too: $i$ Mokošb čtut $i$ Kylou i Malakiju iže estb roučbnyj bloudb velmi počitajut, rekušče Bujakini "And they worship Mokosh' and Kila and Malakiya (that is masturbation) that they worship to a great extent, calling it Buyakinya" (Slovo sv. Grigoriya; see Ivanov \& Toporov 1983: 179). Judging upon the manuscript $O$ trebokladenii idol'skom from the fourteenth century, Mokošb was very popular among women, irrespective of their social status: i Mokošě i da išče sja ne javě moljatb, da otai prizyvajuče idolomolbče baby, to že tvorjat ne tokmo xudii ljudie, nъ i bogatyxъ mužii ženy (Ivanov \& Toporov 1983: 179) "And they pray Mokosh' to manifest herself, and the idol-worshipping women invoke her in secret, and the wives of the rich men perform the same, not only the poor ones". One can find references to Mokošb in the sixteenth century lists of sample questions asked during confession:

Li splutila esi z bagomi bogomerbsyja bludy, li molilasja esi vilamb, li rodu i roženicams i Perunu, i Xorbsu, i Mokoši, pila i ela (Ustavъ prep. Savy; Ivanov \& Toporov 1983: 180).

Did you perform fornication in honour of the gods of blasphemy, did you pray either to vilas, or to Rod, or to rozhenitsas, and did you drink and eat [in honour either of] Perun, or Khors, or Mokosh'. ${ }^{4}$

It is remarkable that the cult of Mokošb, or respect for Mokošb, continues in Russian and Ukrainian folklore until the nineteenth and the twentieth century. In the Chernovetskij district the dirty ghost Mokošá was feared. In the Cherepovetskij district women were warned: ne ostavaj kužlja, a to Mokoša oprjadeti "Do not leave your tow, lest Mokosh' spin it". In the

\footnotetext{
4 Cf. also Khudiye sel'skiye nomokanuntsy: Ne xodila li esi k Mokošb? "Did you go to Mokosh'?" (Ivanov \& Toporov 1983: 180).
} 
Olonetskaja gubernia the sheep moulting was commented by saying $o j$, Mokuša strižet ovec "Oh! Mokusha is shearing the sheep". At the village of Krasilovka (Kozeletsky district) the following folklore text was recorded. It mentions two pagan deities, Posvistach and Mokosh':

Ne est se bog naš Posvistač Bog nastojaščij,| ščo vin sesii buri ne vtišiv, | da naši korabli v takij sili potopiv. | Deś naš bog Posvistač spav, | či v Mokoši guljav .. (Ivanov \& Toporov 1983: 183)

Our god Posvistach is not a true God, / for he did not calm down this storm, / and had our ships drowned in such a tempest. / Our god Posvistach slept somewhere, / or spent time with Mokosh'.

In the dialects of the Moscow region the term mokos' $j a$ is used for a woman of bad morals (Ivanov \& Toporov 1985: 185). In neighbourhood of Novgorod the word mókuš designates a water nymph (ESSJ 1993: XIX 131).

Outside of the East Slavic languages the theonym has left only a few traces. In the mythological context the following proper names are attested: Serbo-Croatian Môkoš 'mighty supernatural power', Czech Mokoš 'deity of wetness' and the curse mokeš (ESSJ 1993: XIX 131). In Slovenian folklore the witch called Mokoška is known. The same word was used for some plants in Slovenian: mokóš m. 'Gallinula, Rallus aquaticus, Crex porzana', mokôška f. 'Ortygometra crex Porzana' (ESSJ 1993: XIX 131). Other reflexes occur in toponymy: Slovenian river-name Mokoš, Czech hill and village Mokošin in Eastern Bohemia, Polabian toponym Muuks/ Mukus, Polish Mokoszyn, Mokosznica, Old Russian village Mokošina, Belorussian marsh Mókšava balóta etc. (Ivanov \& Toporov 1983: 186-88; ESSJ 1993: XIX 131).

Etymology: The closest appellative occurs in Ukrainian mokós $\mathrm{m}$. 'meadow inundated during floods' ( "mokosb), cf. also the toponym Mokos from the neighbourhood of Zagreb (ESSJ 1993: XIX 130), all from the Slavic root *mok- : *mak-, attested also in *mokrb 'wet', *moknoti 'to be out in the rain, become wet', *močiti 'to dip' vs. *makati 'to dip', etc. (ESSJ 1993: XIX 49-85). Old Irish macha, gen. macha m. also means 'enclosure for milking cows, a milking-yard or field', the derivative machaire 'large field or plain' (DIL: M 11-12). A common semantic denominator for both Slavic *mokosb and Old Irish macha could be "wet 
soil', further leading to the meanings 'field, meadow' on the one hand and 'water nymph', 'fairy' or 'goddess of fruitfulness' on the other hand.

\section{Middle Welsh Pwyll, lit. 'wisdom' < Celtic * $\boldsymbol{k}^{w} e i s l o-\sim$ Old Czech Premyzl $\sim$ Primizl}

The words Pwyll penndeuic Dyuet, "Pwyll, chieftain of Dyved", open the First Branch of the Mabinogi. The proper name Pwyll means 'sense, discretion' in Middle and Modern Welsh. It is also preserved in Old Welsh m. puil 'wisdom' (Falileyev 2000: 134). The corresponding forms in other Celtic languages are Old Cornish gurbulloc gl. 'insanus', Breton m. poell, Vanetais pouil, poel 'sense, reason' and Old Irish f. cíall 'sense, intelligence, mind' < * $k^{w}$ eislā (Schrijver 1995: 224, 230; de Bernardo Stempel 1999: 224-25).

The same characterisation was used by authors of the two oldest histories of the first dynasty of Czech kings, Přemyslids, about its legendary founder. The name Premizl was first mentioned in the so-called Legenda Christiani written at the end of the tenth century:

post hinc invento quodam sagacissimo atque prudentissimo viro, cui tantum agriculture officium erat, responsione phitonisse principem seu gubernatorem sibi statuunt, vocitatum cognomine Premizl, iuncta ei in matrimonio supramemorata phitonissa virgine (Ludvíkovský 1978: 19, §2.9-10).

Afterwards, finding a very ingenious and prudent man, who was interested only in ploughing, called Premizl, they established him as a prince or ruler in agreement with the pronouncement of the prophetess, giving him as a wife the virgin-prophetess mentioned above.

The second reference occurs in the Chronica Boemorum of Cosma of Prague, written at the beginning of the twelfth century (Cosma of Prague died in 1125). The author describes how domna Lubossa gives instructions to a messenger who has to fetch her beloved:

... et adducite vobis ducem et mihi maritum. Viro nomen est Primizl ( Premizl), qui super colla et capita vestra iura excogitabit plura; nam hoc nomen latine sonat premeditans vel superexcogitans. Huius proles postera hac in omni terra in eternum regnabit et ultra (Bretholz 1923: I.5).

... and fetch a ruler for you and husband for me. The man is called Primizl, who will invent numerous laws for your necks and heads, because the name 
sounds premeditans 'thinking, thoughtful' or superexcogitans 'inventing' in Latin. His descendants will rule this country for ever.

Elsewhere he is called a 'ploughman': post hec indutus veste principali et calciatus calciamento regali acrem ascendit equum arator (Bretholz 1923: I.7). Let us stress that in both cases it is the woman, Rhiannon and Lubossa respectively, who chooses her husband.

\section{Gaulish ratet 'he pledges, promises, guarantees', Old Irish ráth} 'surety, guarantor, suretyship; guarantee, pledge' Slavic *rota 'oath'

Gaulish ratet 'he pledges, promises, guarantees' occurs twice in the text from Larzac. Meid proposes the following interpretation:

ULATUCIA RAT[ET] (MATIR) BANONIAS NE INICITAS BIONTUTU IN DAS MNAS UERONDAS BRICTAS (Larzac 1b5-7)

Vlatucia, Mutter der Banonia, soll versprechen, dass sie nicht Angriffe schlagen werden gegen die zwei schändlichen zauberkräftigen Frauen (Meid 1996: 46-47).

\section{RATET SEUERA TERTIONICNA NE INCITAS BIONTUTU (Larzac 1b10-11)}

Es soll Severa (und) Tertionicna versprechen, dass sie nicht Angriffe schlagen werden (Meid 1994: 46).

The Old Irish ráth 'surety, guarantor, gl. creditorum; suretyship: guarantee, pledge' (DIL: R 16-17) and Old Breton rad gl. stipulationis can be compared to Gothic frodaba 'intelligently', frodei 'wisdom', Old Icelandic fróðr 'wise, understanding' and Gothic frapi 'mind, understanding', frapjan 'to think, recognise, understand', Old High German frad gl. strenuus, efficax (LEIA: R 9; Lehmann 1986: 126). It reflects the apophonic pair *prāt- : *prə 2 t- that is encountered in Old Irish ráth vs. Old Breton rad and, perhaps, Gaulish ratet. From the point of view of historical phonology, the Celtic and Germanic forms correspond exactly to each other. Ultimately, it is possible to proceed in our analysis to the IE stem * perH $_{3}$-, reflected in the Old Irish verb ernaid 'bestows, grants' (DIL: E 172), see Meid (1996: 46) and Schrijver (1995: 90, 177-78).

On the other hand, Vendryes inquires what the semantic development was leading to the meanings of the Celtic words. He mentions the comparison 
made by Stokes who compared Old Irish ráth with Latin rata 'arbitrata, firma, certa', although Vendryes himself does not exclude a borrowing of a specific Celtic juridical term here (LEIA: R 9). But usually it has been connected with rătus 'established, firm, sure, certain, valid', originally 'reckoned, calculated', part. act. or pass. from the verb reor 'I reckon, calculate; believe, think, suppose, imagine, judge, deem' (Lewis \& Short 1896: 1566). The same $t$-extension of the root * $r \partial_{2}$ - occurs in Latin ratio 'account', Gothic rapjo 'account, explanation', Old Saxon reðia 'speech, word, account' etc. (Lehmann 1986: 281-82).

Slavic *rota 'oath' $>$ Serbo-Croatian ròta, Slovenian róta, Old Czech rota, Polish rota, Old Russian rota, Russian rotá 'id.' (Vasmer 1987: III 507), cf. also Serbo-Croatian pőrota, Czech porota 'jury' and Old Church Slavonic rotiti sę 'detestari', Slovenian (18th cent.) rotim '(be)schwöre' etc. (ESSlnJ: III 198-99).

Etymology: Slavic *rota 'oath' can be both a cognate of, and a borrowing from Celtic $*_{r a t} \bar{a}$, if it represents older $*_{r ə t} \bar{a}$. If the Celtic forms reflect *prətă, the only explanation that remains for the Slavic forms is borrowing from Celtic.

\section{Conclusion}

In the present study four Celtic-Slavic correspondences in mythology and sacral lexicon were analysed. Although the idea of a common heritage (so Victor Kalygin) cannot be excluded, the borrowing or adaptation of the Celtic theonyms and sacral terms seem to be a more probable explanation. In this case, it is legitimate to ask, where was the contact territory? The examples 1, 2 and 4 are Common Slavic. Thus it means that the borrowing had to be realised before the break up of Slavic, i.e. earlier than the Slavs expanded from their homeland. Accepting the localisation of the Slavic homeland on the North-Eastern slopes of the Carpathian Mountains, it is possible to identify the Celtic neighbours of the Slavs with the inhabitants of the town Kappódovvov (Ptolemaios III 5: 15), located in the upper Dniester. The city-name has been etymologised as 'stony-town', cf. Middle Irish carric 'rock, stone', Old Welsh carrecc gl. scropea, Cornish carrag, Old Breton carrec, Old Brython sylva Carrec etc. (Stokes \& Bezzenberger 1894: 72). ${ }^{5}$ The form without the velar extension is perhaps reflected in [Eds.] 
Carrus, the Gaulish epithet of the god Mars, continuing in the name of the mountain Pic-du-Gar' (Holder 1896: I 815-16). This etymology gives a

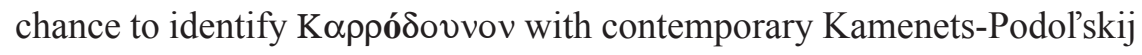
from the South-West Ukraine. The comparison of Pwyll vs. Premyzl represents a correspondence of parallel motifs. In any case, the name of a hero characterised by his intelligence is rather rare when compared to the great number of heroes named on the basis of their martial prowess.

Masaryk University, Brno

\title{
Abbreviations
}

ESSJ - Etimologicheskij slovar' slavyanskikh yazykov

(see Trubachov et al. 1974);

ESSlnJ - Etimološki slovar slovenskego jezika

(see Bezlaj, Snoj, \& Furlan 1995);

YBL - The Yellow Book of Lecan (see Atkinson 1896).

\author{
SUMMARY \\ VÁCLAV BLAŽEK
}

\section{KeLTO-SLOVANSKÉ PARALELY V MYTOLOGII A SAKRÁLNÍ SLOVNÍ ZÁSOBĚ}

V ČLÁNKU JSOU ROZEBRÁNY 4 KELTO-SLOVANSKÉ P ARALELY V M YTOLOGICKÉM A SAKRÁLNÍM SLOVNíkU: 1. STाR Dagdae strus. Dažbbogъ; 2. Stir. Macha < kelt. *Makasiā $~$ strus. Mokošb; 3. Velš. Pwyll, doslova "rozum" < kelt. * $k^{w}$ eislo- $\sim$ stčes. Premyzl Primizl, glosováno 'praemeditans'; 4. Gal. (Larzac) ratet "ručí, slibuje”, stir. ráth "ručitel, garant, gl. ‘creditorum”; záruka, garance” sl. *rota "přísaha”. Ačkoliv idea společného (západo)indoevropského dědictví, jak ji formuloval Viktor Kalygin (p.c., Bonn 1998) nemůže být vyloučena, výpůjčka či adaptace keltských theonym a sakrálních termínů se zdá být slibnějším východiskem. Pak je třeba se ptát, kde kontakt proběhl. Slovanský materiál ze srovnání 1,2 a 4 je rozširřren ve všech slovanských větvích, prrípadná výpůjčka by musela proběhnout ještě před rozpadem slovanského prajazyka. Akceptujeme-li lokalizaci slovanské pravlasti na severovýchodní svahy Karpat, je možno identifikovat keltské sousedy Slovanů

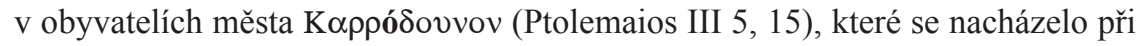
horním Dněstru. Toponymum může být etymologizováno jako "kamenné město", srov. střir. carric "skála, kámen”, stvelš. carrecc gl. 'scropea', korn. carrag, stbret. carrec, stbrit. sylva Carrec etc. (Stokes \& Bezzenberger 1894: 72). Forma bez velárního rozšíření je patrně odražena v přívlastku Carrus, který patřil galskému 
Martovi, a který je možno též identifikovat ve jménu hory Pic-du-Gar' (Holder 1904: II 815-16). Tato etymologie dává šanci položit rovnítko mezi toponymum Kappódovvov a současné jméno města Kamenets-Podol'skij na jihozápadě Ukrainy. Srovnání 3, kde je spojován velšký hrdina Pwyll "rozum" a legendární zakladatel první české královské dynastyie Premyzl "přemýšlející", představuje paralelní motiv. Exkluzivita tohoto srovnání spočívá v mnohonásobné preferenci motivace typu "válečník, silák" apod. nad motivací vyzdvihující inteligenci. 